\title{
Norme vir huidiglik
}

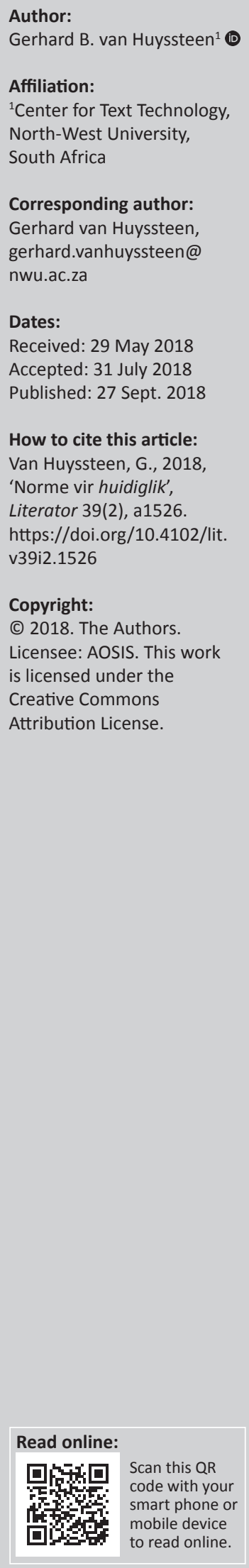

Norms of huidiglik. In Afrikaans, huidiglik is a truly Janus-faced word: it is being used with high frequency in especially spoken language, while at the same time being one of the biggest language pet-peeves of language practitioners (and even ordinary speakers of Afrikaans). When asked why huidiglik should be avoided, these language practitioners and language users often cannot provide any reasoning about it. A comprehensive literature review also reveals that linguists and language practitioners often give contradictory, or even linguistically incorrect reasons for why huidiglik is supposedly not acceptable in (standard) Afrikaans. By comparing a variety of normative grammaticographic sources (such as reference guides and prescriptive grammars), this article shows that: (1) huidiglik originated, on a balance of probability, in the 1970s in the South African Parliament; and (2) apart from stylistic preferences (e.g. that it sounds pretentious, feigned and affectatious), none of the linguistic arguments against huidiglik holds water. In a supplementary article in this issue of the journal it is being illustrated that huidiglik is alive and well in written (Standard) Afrikaans.

\section{Inleiding}

Die woord huidiglik kan met reg 'n tweestertjakkals in die Afrikaanse woordeskat genoem word. Aan die een kant is dit 'n woord wat in gesproke Standaardafrikaans 'steeds in elke derde sin opduik' (Kapp 2014), maar aan die ander kant word dit dikwels eerste genoem as dié taalverskynsel wat 'n 'doring in menige se vlees is' (Luther \& Pheiffer 2013).

Die eerste opname van huidiglik as lemma in 'n Afrikaanse woordeboek, vind 'n mens in die derde uitgawe van die Handwoordeboek van die Afrikaanse Taal (Odendal 1994; voortaan HAT, met uitgawenommer in boskrif, ook wanneer verwys word na Luther, Pheiffer \& Gouws 2015):

hui'dig.lik bw. Nieuvorming waarvan die gebruik deur die meeste kundiges afgekeur word; tans, nou, op hierdie oomblik, teenswoordig, in hierdie tyd.

Metterjare het die inskrywing in die HAT grootliks onveranderd gebly, behalwe dat in die jongste uitgawe met die klassifikasie as nieuvorming weggedoen word. Die enigste ander aanlyn woordeboek wat eksplisiet (anders as byvoorbeeld implisiet in voorbeeldmateriaal) melding van huidiglik maak, is die Pharos Groot Woordeboek Afrikaans en Nederlands (ANNA 2011):

huidig b.nw., huidige b.nw. (Opm. 1. In Afr. word 'huidige' slegs attributief en in die verboë vorm gebruik. 2. In Afr. word 'huidig' en 'huidiglik' in bywoordelike funksie dikwels gehoor, maar dit word deur kundiges meestal as onaanvaarbaar beskou).

Gegewe hierdie woordeboekinskrywings, kan woordeboek- en ander taalgebruikers met reg vra:

1. Wie is hierdie kundiges waarna die woordeboeke verwys, en wat is hulle argumente teen die gebruik van huidig en huidiglik?; en

2. Beide woordeboeke stel dit dat huidiglik 'dikwels' gebruik word. Hoe dikwels word huidiglik in eietydse Afrikaans gebruik?

Die doel van hierdie artikel is om die eerste van hierdie twee vrae te beantwoord; die tweede vraag (en ander subvrae wat in hierdie artikel geopper word) word in Van Huyssteen (2018) behandel. In die volgende afdeling word die bronne wat vir hierdie navorsing gebruik is, breedvoerig bespreek. Daarna word probeer om die oudste optekening van huidiglik na te speur, ten einde die gesprek oor die woord te kontekstualiseer. In die daaropvolgende afdelings word alle taalkundige argumente wat al oor huidiglik en sy basiswoord huidig (voortaan huidig[lik]) aangevoer is, opgesom en beoordeel. Ten slotte word hierdie gegewens oorweeg om 'n standpunt te formuleer oor die interne norme (d.i. met betrekking tot grammatikaliteit) (Carstens 2018:28) wat tans ten opsigte van huidig(lik) sou kon geld. 


\section{Bronne}

Benewens die artikels in bogenoemde woordeboeke, kan literatuur oor huidiglik in drie genrekategorieë verdeel word:

1. Populêre literatuur:

a. Tydskrifartikels of koerantrubrieke

b. (Mikro)blogs op die wêreldwye web (www)

c. Reaksies deur taalgebruikers in die gedrukte media en op die www

2. Normatiewe grammatikografiese literatuur:

a. Inskrywings in naslaangidse

b. Besprekings in grammatika-, styl- en handboeke

3. Wetenskaplike literatuur: Slegs een wetenskaplike artikel is aan huidiglik gewy, te wete Prinsloo (2003) se leksikografiese beskouing.

In hierdie artikel word primêr gebruik gemaak van 'n vergelykende grammatikografiese studie, d.i. 'n vergelyking van die literatuur in 2 . hier bo. Die volledige versameling van 40 grammatikografiese bronne wat deur Kirsten (2016:62-65) geïdentifiseer is, is as wegspringplek gebruik. Hierdie versameling is aangevul met soveel as moontlik ander soortgelyke bronne waarin iets oor huidig(lik) gesê word, waarna ander literatuur soos in 1. en 2. hier bo genoem, betrek is. Alle beskikbare literatuur word in Tabel 1 opgesom.

Ter wille van 'n diachroniese perspektief, word slegs drie outeurs of bronne wat nié huidig(lik) vermeld nie, in Tabel 1 opgeneem, te wete De Villiers (1959) vir 'n vergelyking met De Villiers (1981; 1986); Du Plessis (1979) vir 'n vergelyking met Du Plessis (1981); en Van der Merwe (1956; 1967) vir 'n vergelyking met Van der Merwe en Ponelis (1982; 1991). Om dieselfde redes van diachroniese vergelyking, word verskillende uitgawes van dieselfde bron ook soms ingesluit, byvoorbeeld én Carstens (1989) én Carstens (2018); én Müller (2003) én Müller en Pistor (2011); ensovoorts.

Tensy anders vermeld, kom alle voorbeeldmateriaal in hierdie artikel uit die versameling tekste in die Virtuele Instituut vir Afrikaans se Korpusportaal: Omvattend (voortaan VivA-KPO; VivA 2018); kyk Van Huyssteen (2018) vir 'n uitvoerige uiteensetting van hierdie versameling.

\section{Oudste optekening van huidiglik}

Soos wat uitlatings oor die frekwensie van huidiglik dikwels anekdoties is, so ook is die enigste optekening oor die eerste voorkoms van die woord. In een van sy bundels herinneringe skryf oudpolitikus Japie Basson uitgebreid oor huidiglik (Basson 2006:168-171). Hy waag 'n bewering 'dat huidiglik sy reis in die Volksraad by John Vorster begin het tydens 'n bespreking van sy begrotingspos as Eerste Minister' - iewers rondom 1971 (d.i., 'ongeveer vyf-en-dertig jaar gelede'). Hy vertel:

By die behandeling van 'n begrotingspos in die ou Volksraad is die minister wie se pos onder bespreking was, onbeperkte tyd toegelaat om op vrae en kritiek te antwoord. ... [P]remier Vorster [het] die gewoonte gehad om by sý posbehandeling rustig met die een voet op die sitbank te staan, sy elmboog op die knie te laat rus en met die ander hand tussen die notas op sy lessenaar te vroetel om te besluit op wie en waarop hy volgende wou antwoord. So soekende het hy gewoonlik aanhou praat, meestal dralend totdat hy weer met sy antwoord koers ingeslaan het.

Dit was met so ' $n$ oorgang van een onderwerp na' $n$ ander waarin hy sy woorde as 't ware laat sleep het, dat die Eerste Minister die woord huidig gebruik het, en 'n merkbare oomblik later die -lik daaraan gelas het. (Basson 2006:169)

Gegewe dat die Hansardverslae van daardie jare nie digitaal beskikbaar is nie, is dit byna onmoontlik om 'almal na te slaan om die bewysplaas te probeer vind' (id.). Selfs al sou 'n mens so ' $n$ handmatige soektog begin, is 'n mens nie eers seker dat 'die Hansard-skrywers se snelskrif dit inderdaad opgeneem het' nie (id.).

By 'n gebrek aan bewyse vir die teendeel, wat is die oorwig van waarskynlikheid dat hierdie anekdote waar is of sou kon wees? Hier volg 'n paar argumente:

- Die Eerste Minister se toesprake het in daardie dae veel gewig gedra, en die waarskynlikheid is dus groterig dat ander amptenare (insluitende Hansardskrywers, vertalers en teksredakteurs) kennis sou neem van sy taalgebruik, al was dit dalk selfs onbewustelik. Soos Basson (id.) dit stel: '... die feit [is] dat die jaarlikse omvattende bespreking van 'n Eerste Minister se stuurmanskap as so 'n belangrike debat gegeld het dat dit die één geleentheid was waar dit vir die hoë amptenare van al die departemente nodig was om in hul sekretariële banke teenwoordig te wees'.

- Die feit dat die eerste kommentaar op huidiglik in 1981 verskyn (kyk Tabel 1), gee moontlik'n aanduiding dat die woord eers in die 1970s sy opwagting in gesproke Afrikaans gemaak het. De Villiers (1981) beweer dat ' $[k]$ abinetsministers, politici, predikante, landbouamptenare, studente en ander ... die woord soms op hierdie manier [gebruik], veral by openbare geleenthede' [outeur se eie nadruk].

- Die oudste sitaat in geskrewe Afrikaans wat met behulp van 'n Googlesoektog opgespoor kon word, dateer uit 1974 en dan wel in 'n akademiese konteks. In die Journal of the South African Veterinarian Association word die 1973-presidentsrede (dus gesproke teks) van A.B. la Grange (1973) gepubliseer, waarin hy sou sê: 'Die Staat is vir 30 jaar nie meer die enigste werkgewer nie en huidiglik staan meer as 50 persent van ons lede slegs in die private praktyk'. (Let wel: Binne 'n kwessie van 'n maand waartydens hierdie artikel geskryf is, het die datum van die oudste publikasie in Google Books verskuif vanaf 1981, tot 1977, tot 1975, tot 1974 - soos wat meer publikasies gedigitaliseer en aanlyn verskyn het. 'n Mens kan dus nie met hoë sekerheid op 1974 as die oudste publikasiedatum van huidiglik reken nie.)

- In Afrikaanse taalkwessies (Van der Merwe 1956) en sy opvolguitgawe Die korrekte woord (Van der Merwe 1967) word geen sprak gesprook oor huidig(lik) nie, maar vanaf 


\begin{tabular}{|c|c|c|c|c|c|c|c|c|c|c|c|c|}
\hline \multirow[b]{2}{*}{ Outeurs } & \multirow[b]{2}{*}{ Jaar } & \multirow[b]{2}{*}{ Genre } & \multirow[b]{2}{*}{ Korrek } & \multirow[b]{2}{*}{ Gangbaar } & \multicolumn{4}{|c|}{ Steurend } & \multicolumn{4}{|c|}{ Foutief } \\
\hline & & & & & stil. & mod. & veroud. & onekon. & w.soort & w.vorm & angl. & geen \\
\hline Carstens & 1989 & (Hand)boek & - & - & $x$ & $x$ & - & - & $x$ & - & - & - \\
\hline Carstens & 2003 & Rubriek & - & - & $x$ & - & - & - & - & - & - & $x$ \\
\hline Carstens & 2018 & (Hand)boek & - & - & $x$ & $x$ & - & - & $x$ & - & - & - \\
\hline Combrink & 1993 & Rubriek & - & - & $x$ & - & - & - & - & - & - & - \\
\hline Combrink & $1995 a$ & Rubriek & $x$ & - & - & - & - & $x$ & - & - & $x$ & - \\
\hline $\begin{array}{l}\text { Combrink (ook oor } \\
\text { huidig) }\end{array}$ & $1995 b$ & Rubriek & - & $x$ & - & - & - & - & - & - & - & - \\
\hline Combrink & $1995 c$ & Rubriek & - & - & $x$ & - & - & - & - & $x$ & $x$ & - \\
\hline Combrink & 1996 & Rubriek & - & $x$ & $x$ & - & - & - & - & - & - & - \\
\hline Combrink en Spies & 1994 & Naslaangids & - & - & $x$ & - & - & $x$ & - & $x$ & $x$ & - \\
\hline De Villiers & 1959 & Naslaangids & - & - & - & - & - & - & - & - & & - \\
\hline $\begin{array}{l}\text { De Villiers (oor } \\
\text { huidig[lik]) }\end{array}$ & 1981 & Rubriek & - & - & - & $\mathrm{x}$ & $x$ & - & - & - & $x$ & - \\
\hline De Villiers (oor -lik) & 1986 & Rubriek & - & - & $x$ & - & - & - & $x$ & - & - & - \\
\hline Du Plessis & 1979 & Naslaangids & - & - & - & - & - & - & - & - & - & - \\
\hline $\begin{array}{l}\text { Du Plessis (oor } \\
\text { huidig) }\end{array}$ & 1981 & Naslaangids & - & - & - & - & - & - & $x$ & - & - & - \\
\hline Eksteen & 1985 & Rubriek & - & - & $x$ & $\mathrm{x}$ & - & - & $x$ & $x$ & - & - \\
\hline Hiemstra (oor -lik) & 1980 & Naslaangids & - & - & - & - & $x$ & $x$ & - & - & $x$ & - \\
\hline Kapp & 2014 & Blog & - & - & - & - & - & - & - & - & & $x$ \\
\hline Luther en Pheiffer & 2013 & Naslaangids & - & - & - & - & - & - & $\mathrm{x}$ & $x$ & $x$ & - \\
\hline Müller & 2003 & Naslaangids & - & - & - & - & - & - & $x$ & - & - & - \\
\hline Müller en Pistor & 2011 & Naslaangids & - & - & - & - & - & - & $x$ & - & - & - \\
\hline Prinsloo & 2003 & Wetenskaplike artikel & - & $x$ & - & - & - & - & - & - & - & - \\
\hline Prinsloo & 2013 & Rubriek & - & $x$ & - & - & - & - & - & - & - & - \\
\hline Prinsloo en Odendal & 1995 & Naslaangids & - & - & - & - & $x$ & $x$ & - & - & - & - \\
\hline Scholtz & 1990 & Rubriek & - & - & $x$ & - & - & - & - & $x$ & - & - \\
\hline Spies & 1990 & Rubriek & - & - & - & - & - & - & - & $x$ & - & - \\
\hline Van der Merwe & 1956 & Naslaangids & - & - & - & - & - & - & - & - & - & - \\
\hline Van der Merwe & 1967 & Naslaangids & - & - & - & - & - & - & - & - & - & - \\
\hline $\begin{array}{l}\text { Van der Merwe en } \\
\text { Ponelis }\end{array}$ & 1982 & Naslaangids & $x$ & - & $x$ & - & - & - & - & - & $x$ & - \\
\hline $\begin{array}{l}\text { Van der Merwe en } \\
\text { Ponelis }\end{array}$ & 1991 & Naslaangids & $x$ & - & $x$ & - & - & - & - & - & $\mathrm{x}$ & - \\
\hline
\end{tabular}

stil., stilisties; mod., modieus; veroud., verouderd; onekon., onekonomies; w.soort, woordsoortelike gebruik; w.vorm, woordvorming; angl., anglisisme.

die 1982-uitgawe (Van der Merwe \& Ponelis 1982) word huidig(lik) uitvoerig behandel. Hieruit kan 'n mens dalk ook aflei dat huidiglik eers in die 1970s ontstaan of toegeneem het.

Of huidiglik daadwerklik in die mond van John Vorster ontstaan het, is moeilik te bewyse. Daar is egter genoeg argumente om met 'n hoë mate van sekerheid aan te neem dat huidiglik in die 1970s in die gesproke Afrikaans van amptenare beslag gekry het.

Die normatiewe en preskriptiwistiese gesprek rondom huidiglik moet ook teen hierdie agtergrond gesien, verstaan en beoordeel word. Aan die een kant kan 'n mens sê dat daar in die 1980s en 1990s'n hoogbloei in die publikasies van normatief grammatikografiese bronne was - vergelyk byvoorbeeld in Tabel 1 die relatief groot getal naslaangidse wat in hierdie twee dekades verskyn het, teenoor die getal in die tydperk 2000 tot 2018. Daar was dus duidelik in hierdie tyd ' $n$ groot behoefte aan en ' $n$ mark vir sulke normatiewe naslaangidse, en van die prominentste Afrikaanse taalkundiges en taalpraktisyns het gewoon aan dié behoefte beantwoord.

Aan die ander kant had dié skrywers nie geredelik toegang tot korpusse en middele om korpusse te deursoek nie.
Standpunte is daarom dikwels op eie ervaring, waarnemings en intuïsie geskoei - soos die heersende en aanvaarbare praktyk in die taalkunde in hierdie tydperk was. Met hierdie en die komplementêre artikel (Van Huyssteen 2018) wil ek dus die hiaat vul deur die gesprek oor huidiglik binne 'n kontemporêre, deskriptiewe raamwerk te plaas, asook om die winste van ' $n$ korpuslinguistiese benadering tot voordeel van die debat aan te wend.

\section{Grammatikografiese vergelyking}

In Tabel 1 word 'n opsomming van al die beskikbare grammatikografiese literatuur oor huidig(lik) gegee. By elke bron word ' $n$ interpretasie gegee, d.i. of die outeur huidig(lik) as korrek, gangbaar, steurend (maar nie noodwendig verkeerd nie) of foutief beskou. Die argumente van elk van hierdie kategorieë word hier opgesom.

- Korrek: Van der Merwe en Ponelis (1982; 1991) is voorlopers om te sê dat die bywoordelike gebruik van huidig(lik) nie noodwendig verkeerd is nie, maar voeg by dat dit stilisties steurend is (' ... hoewel dit maar bra deftig en boekerig klink'). Ofskoon Combrink ook huidiglik in die meeste van sy publikasies afkeur (kyk hier onder), sê hy tog dat die ·lik-morfeem 'n nadruksfunksie kan hê: '... 
die fyn spreker of skrywer gebruik dié -lik om te sê: ek is ernstig. Dink maar aan die "“onlogiese" goddelooslik'. (Combrink 1995a; kyk egter ook hier onder vir sy kritiek teen die gebruik van die $\cdot$ lik-morfeem).

- Gangbaar: Op grond van gebruiksfrekwensie in die spraakmakende gemeenskap meen Combrink (1995b; 1996) en Prinsloo (2003; 2013) dat huidig(lik) in bywoordelike funksie wel as gangbare Afrikaans beskou moet word en dat woordeboeke hierdie werklikheid behoort te reflekteer. Soos Combrink (1995b) dit stel: '... huidig is huidig deel van die taalskat van meningvormende Afrikaanssprekendes. En as huidig deel is, dan is daar ook nie meer geldige besware teen huidiglik nie'.

- Steurend: 'n Aantal argumente word aangevoer waarom die gebruik van huidig(lik) steurend is, selfs al is dit nie noodwendig foutief nie:

- Stilisties: Die meerderheid outeurs beskou huidig(lik) as 'oormatig deftige Afrikaans' (Carstens 2018). Combrink noem huidig(lik) in verskeie publikasies 'n 'amptenaraanse tydsbywoord' wat ontstaan het uit 'deftigdoenery' (1993).

- Modieus: Die heel eerste beskouing van huidig(lik) deur 'n taalkundige is De Villiers (1981) se siening dat dié twee woorde modeverskynsels in Afrikaans is, wat veral deur ' $[k]$ abinetsministers, politici, predikante, landbouamptenare $[e n]$ studente $\ldots$ by openbare geleenthede' gebruik word. Sy standpunt sluit dus by die amptenaraanse siening aan, aangesien huidig(lik) die 'goeie ou gewone woord met sy duidelike betekenis en funksie' (Eksteen 1985:29) verdring.

- Verouderd: Teenoor (of in samehang met?) sy beskouing dat die gebruik van huidig(lik) 'n modeverskynsel is, wys De Villiers ses jaar later (1986) daarop dat die gebruik van adverbialiserende ·lik 'nie deesdae in Afrikaans aan te beveel [is] nie'. Hy sluit eksplisiet by Hiemstra (1980:32, 72-73) aan wat skryf dat in die hedendaagse taal het die -lik oortollig geword en gebruik ons dit slegs as 'n bewus argaïese (ouderwetse) vorm, wat by 'n aantal woorde te pas kom om soms 'n deftige of Bybelse kleur daaraan te verleen' (1980:72). Prinsloo en Odendal (1995:80) is selfs van mening dat die gebruik van huidiglik aan ' $t$ afneem is in 'openbare toesprake' (maar agt jaar later meen Prinsloo (2003) wel dat huidiglik sodanig gevestig is dat dit verdien om in woordeboeke opgeneem te word).

- Onekonomies: Talle outeurs suggereer of sê eksplisiet dat adverbialiserende ·lik 'oorbodig [of] langdradig' (Combrink 1995a) is, aangesien die meeste bywoorde meestal sonder die $i k$ kan staan 'met weinig verlies' (Combrink \& Spies 1994:76), of dat 'ekonomiese alternatiewe' (Prinsloo \& Odendal 1995:80) gebruik kan word. Menige outeur stel dit egter duidelik dat daar niks fout is met die adverbialiserende ·lik nie, veral waar dit met 'n nadruksfunksie gebruik word (byvoorbeeld 'Sekerlik!' teenoor 'Seker!'). ${ }^{1}$

1. In 'n informele meningsopname wat op 18 April 2018 in ' $n$ Afrikaanstalige Facebookgroep geplaas is (https://www.facebook.com/groups/taalgoggas/ permalink/1821128854584585/), dui $81 \%$ van die 239 respondente aan dat hulle
- Foutief: Sommige skrywers wat huidig(lik) steurend vind, dui ook aan dat dit foutief is, byvoorbeeld Scholtz (1990) wat huidiglik nie net steurend vind nie, maar ook aandui dat dit van 'twyfelagtige herkoms' is. Ander outeurs (bv. Spies 1990) meen dat huidig(lik) reëlreg verkeerd is, en wel om die volgende aaneengeslote redes:

- Woordsoortelike gebruik: Soos ANNA (2011 [kyk hier bo in die afdeling Inleiding]), wys ook Carstens (2018:134-135) daarop dat huidig(e) in sy gewone gebruik slegs 'n adjektief is. Volgens dié argument kan huidige in Afrikaans gebruik word, terwyl huidig en huidiglik (hetsy as bywoorde of predikatiewe adjektiewe) foutief is. Hoewel geen van die outeurs eksplisiet daaroor is nie, kan 'n mens aflei dat hulle met 'predikatiewe adjektief' eintlik 'onverboë adjektief' bedoel, d.i. dat slegs huidig, sonder die attributiewe $\cdot e$, aanvaarbaar is.

- Woordvorming: Voortspruitend uit die vermeende verkeerde woordsoortelike gebruik, kom die argument dat gebruikers dan huidiglik vorm op basis van die niebestaande huidig:

Die taalkundige beswaar teen huidiglik is dat die stam vóór die $l i k$, waarop die likwoord veronderstel is om gebaseer te wees, nie bestaan nie. Ons ken naamlik in Afrikaans nie huidig nie, net huidige. Anders gestel: likwoorde word in Afrikaans op basis van predikatiewe byvoeglike naamwoorde gevorm. Voorbeelde van likwoorde wat op basis van predikatiewe b.nwe gevorm is, is jammerlik, goediglik en waarlik. Maar ons ken in Afrikaans slegs die áttributiewe huidige, met sy slote. (Combrink 1995c)

Spies (1990) interpreteer die vorming van huidiglik selfs heeltemal anders as ander taalkundiges. Hy wys daarop dat gebruikers:

'dink huidig is soos gretig en vurig met die agtervoegsel -ig gemaak', maar dat dit nie waar is nie: 'Die -dig (nie -ig nie) van huidig is 'n verswakte vorm van dag. Huidig was eers "hierdie dag"' (Spies 1990).

- Anglisisme: Die meeste outeurs wys daarop dat huidiglik se vorming anglisisties is: '[H]uidiglik kon nie spontaan in Afrikaans, volgens Afrikaanse patroon, ontstaan het nie, dit is ' $n$ geforseerd Engelse deelvirdeel [sic] vertaling van presently' (Combrink 1995c). Hierdie argument hou in dat die Engelse adverbialiseerder $\cdot l y$ (bv. in law.ful.ly) nie .lik in Afrikaans as ekwivalent het nie; hiervolgens sou woorde soos wett.ig.lik ook daarom ongrammatikaal wees.

- Geen rede: Twee outeurs (Carstens 2003; Kapp 2014) stel slegs dat huidiglik verkeerd is, maar verskaf geen rede nie.

\section{Beskouing: Huidiglik is steurend}

Geen van die argumente wat aangevoer word dat huidig(lik) stilisties steurend, modieus, verouderend of onekonomies is, bied grondige redes om die woord anders as ander soortgelyke woorde in woordeboeke te behandel, of om gebruikers wat die woord gebruik, te kapittel nie.

'sekerlik' sal antwoord op die vraag: 'Kan jy my dalk gou help?'. Die ander $19 \%$ kies 'seker' as antwoord. 
Sogenaamde stylfoute is immers bloot steuringe (of stylgebreke) wat 'ernstige gebruikers van Afrikaans ... [behoort] te vermy in soverre dit moontlik is' (Carstens 2018:381) [outeur se eie nadruk]. Stilistiese keuses is en bly 'n subjektiewe kwessie van smaak: Wat een taalgebruiker as ' $n$ stylfout in 'n bepaalde konteks beskou, kan binne 'n ander konteks deur 'n ander taalgebruiker as effektief en gepas aanvaar word.

Die feit dat Combrink (1996) huidiglik as amptenaraans beskou, impliseer dat die gebruik van die woord volgens hom tipies in amptenaarstaal aangetref word, en 'n mens sou dan juis kon verwag om huidiglik in 'n korpus van regeringstekste aan te tref, of andersins in ander tekste wat in formele Standaardafrikaans geskryf is. Combrink (1996) gebruik egter die term 'amptenaraans' derogatief, d.i. as die taalgebruik van iemand wat hom of haar deftig en geleerd wil voordoen. Selfs binne hierdie konteks impliseer dit lank nie dat die woord foutief of ongrammatikaal is nie dit is en bly die keuse van die gebruiker om dit binne bepaalde kontekste te gebruik, net soos wat hy of sy na hartelus stopwoorde, clichés, oormatige beeldspraak, modewoorde, argaïsmes, sleng of jargon na gelang van die kommunikasiesituasie mag gebruik.

In Van Huyssteen (2018) word die frekwensie van huidig(lik) ondersoek, ten einde te probeer bepaal of dit steeds as modeverskynsel beskou moet word (De Villiers 1981), of dit juis verouderd is (De Villiers 1986), of dit slegs in amptenaarstaal voorkom, of huidig - soos in Nederlands 'tot de deftige schrijftaal beperkt' is (volgens die artikel uit 1907 in die Woordenboek der Nederlandse Taal (WNT) - De Vries \& Te Winkel 1864-1998), ensovoorts.

\section{Beskouing: Huidiglik is foutief}

Met betrekking tot die sienings dat huidiglik foutiewe Afrikaans is, is daar hoofsaaklik drie argumentasielyne. Elkeen van dié argumentasielyne word in die volgende subafdelings in oënskou geneem.

\section{Argument: Huidig word slegs in sy verboë vorm gebruik en is dus nie beskikbaar vir ander morfologiese prosesse nie}

Alvorens die argument krities oorweeg word, is dit noodsaaklik om waar te neem dat Afrikaans, soos Duits en Nederlands, in den brede geen vormlike onderskeid tussen adjektiewe en bywoorde van wyse maak nie:

Hengeveld (1992:68-69) classifies English typologically as a 'specialized language' ('differentiated' in Hengeveld, Rijkhoff \& Siewierska 2004) because this language has a word-class for both adjectives and manner adverbs, English having developed the adverbial suffix $-l y$. This feature distinguishes English from other Germanic languages, where the unmarked (e.g. Dut. snel, Ger. schnell 'fast') or neuter (e.g. Sw. roligt 'funny') form of the adjective is used for adverbial functions (and some suffixes for specific functions). To put it in the words of Hengeveld (1992:65), Dutch (and other Germanic languages) 'combines the functions of adjectives and manner adverbs'. (Hummel 2014:35) [outer se eie nadruk]
Dit sluit ten nouste aan by Kempen (1969:49) se beskouing dat daar drie kategorieë van adjektiewe en bywoorde in Afrikaans onderskei moet word:

1. Daar is woorde wat tradisioneel b.nwe. genoem word, wat nie bw.-funksies het nie, bv. Stellenbosse, goue.

2. Daar is woorde wat tradisioneel bwe. genoem word, wat nie b.nw.-funksies het nie, bv. gister, oorkant, mos, darem, ens.

3. Daar is woorde wat tradisioneel b.nwe. èn [sic] bwe. genoem word, bv. groot, hard, lelik, sleg, wat in elke opsig dieselfde kenmerke het en dus as één woordsoort beskou kan word, naamlik wat A.S. Theron [1964] Kwaliteitswoorde genoem het. (Kempen 1969:49)

Visueel kan hierdie verdeling met 'n venndiagram soos in Figuur 1 voorgestel word. Kempen (1969) se eerste kategorie word tipies in linguistiese analises (vergelyk bv. Booij 2010) gemerk as ADJ, die tweede as ADV en die derde as A (d.i. die deelversameling van adjektiewe en bywoorde). Benewens die voorbeelde wat Kempen (1969) verskaf, is alle ander ADJvoorbeelde in die diagram woorde wat in $\mathrm{AWS}^{11}$ (Taalkommissie 2017) met die etiket (attr.) gemerk is, wat daarop dui dat dié adjektiewe nie predikatief of as bywoorde gebruik kan word nie; alle ADV-voorbeelde is in AWS ${ }^{11}$ met (bw.) gemerk, wat eksplisiet daarop dui dat hulle nie as adjektiewe gebruik kan word nie.

Anders as Hengeveld (1992) spesifiseer Kempen (1969) nie dat die oorvleueling noodwendig met bywoorde van wyse is nie, maar uit die benoemer 'kwaliteitswoord' (Kempen 1969:49) sou 'n mens wel dalk tog die afleiding kon maak. Van Schoor (1983:59, 110) noem dié soort woorde 'hoedanigheidsbywoorde' en stel dit eksplisiet: '... ons moenie die bywoord en die b.nw. as teenstellings sien nie. Soos die b.nw. na die bywoord kan oorloop, gebeur ook die teenoorgestelde ...' (Van Schoor 1983:59-60; kyk ook Diepeveen \& Van de Velde 2010). Hy verwys na sulke gevalle met identiese vorms maar verskillende funksies as grammatiese homonieme (Van Schoor 1983:62, 110) en gee voorbeelde soos kaalvoet, barvoets, binnensmonds, bloedig,

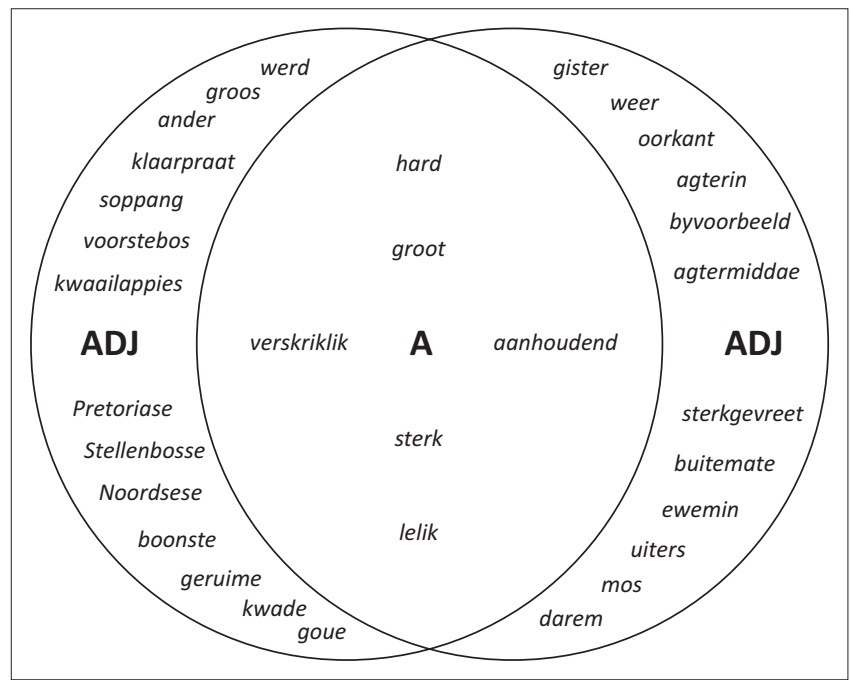

FIGUUR 1: Venndiagram van adjektiewe en bywoorde. 
broekskeur, dwars, goedsmoeds, heftig, inderhaas, ingedagte, maklik, ruimskoots, deeglik, doelbewus, doelgerig, droëbek, drogies, droogweg en eenparig (Van Schoor 1983:110).

Hoewel meer (vergelykende) navorsing oor die saak nodig is, volstaan ek vir die doeleindes van hierdie artikel met die aanname dat die oorgrote meerderheid Afrikaanse adjektiewe ook as bywoorde kan optree. Daar is dus in teorie geen rede waarom huidig nie in sy verboë en onverboë vorm as adjektief kan optree, én in sy onverboë vorm as bywoord sou kon funksioneer nie. Uit korpusdata blyk dit dus ook inderdaad die geval te wees; vergelyk die volgende voorbeelde:

1. Huidig as adjektief: verboë

Hoewel die Wêreldgesondheidsorganisasie (WGO) verklaar het dat die huidige uitbraak van Ebola ' $n$ wêreldwye noodtoestand veroorsaak het, ... bly berigte oor die aansteeklikheid daarvan ... baie teenstrydig.

2. Huidig as adjektief: onverboë

Kuns kan gedefinieer word as 'n vorm van kultuuruitdrukking en kan dui op voorwerpe of uitvoerings, huidig of histories, en die prestige daarvan word ondervind deur diegene wat dit gemaak het, ontdek, uitstal of besit.

3. Huidig as bywoord

Aangesien die Ovambo's die grootste bevolkingsgroep in die land is en ook die meerderheid van die huidig regerende SWAPO-party uitmaak, is die offisiële antagonisme teenoor Afrikaans in 'n mate verstaanbaar.

Soos uit dié gebruiksgevalle blyk, hou die standpunt dat huidig 'slegs attributief en in die verboë vorm gebruik' word (ANNA 2011), nie stand nie. In Van Huyssteen (2018) word die frekwensie en spreiding van sowel huidig(e) en huidiglik(e) verder ondersoek.

\section{Argument: Huidiglik is morfologies wangevormd}

Spies (1990) meen dat huidig morfologies ontleed moet word as hui.dig, waar hui. 'hierdie' beteken en ·dig 'n verswakte vorm van dag is. Daar is egter geen taalkundige gronde vir hierdie analise nie. Alle Nederlandse etimologiewoordeboeke wat by etymologiebank.nl geraadpleeg is, is dit eens dat huidig 'n Oosmiddelnederlandse of Middelnederduitse afleiding van huden, 'n wisselvorm van heden 'hede; vandag' is (Philippa et al. 2003-2009). Dié afgeleide vorm het na alle waarskynlikheid ontstaan na analogie van die Duitse heutig 'met betrekking tot vandag, hierdie dae', wat reeds in die agtste eeu in Oudhoogduits bestaan het as hiutig, of in Middelhoogduits as hiutec of hiutic (Philippa et al. 20032009) - moontlik afgelei van hiutu ('vandag') plus die afleidingsuffiks .ig/.ic (Wiktionary 2018; https://en. wiktionary.org/wiki/heutig). In Middelnederlands is die woord meestal geskryf as hudig(en) (opgeteken uit 1405; Van Veen \& Van der Sijs 1997) of hudich/hûdich (opgeteken uit 1409; Philippa et al. 2003-2009; Van Wijk 1936 [1912]), terwyl ons in Vroeë Nieunederlands huydige(n) aantref (opgeteken uit 1624 en 1664; Philippa et al. 2003-2009). Hierdie etimologiese uitleg van huidig repudieer Spies (1990) se morfologiese analise volledig.
Hoewel huidig eintlik sinchronies as ongeleed beskou kan word (d.i., dat dit gewoon 'n Nederlandse oorerfsel is), sou dit nie verkeerd wees om te sê dat twee morfologiese konstruksieskemas huidiglik ten grondslag lê nie:

4. .ig-skema ${ }^{2}$ :

$$
\begin{aligned}
& {\left[[\mathrm{a}]_{\mathrm{N} / \mathrm{P}} \cdot \mathrm{ig}\right]_{\mathrm{A}} \leftrightarrow\left[\text { MET DIE AARD VAN } \mathrm{SEM}_{\mathrm{N}}\right]_{A}} \\
& \text { bloed } \cdot \text { ig; jeugd } \cdot \text { ig; } \text { af.gunst } \cdot \text { ig; dik } \cdot \text { vell } \cdot \text { ig }
\end{aligned}
$$

5. $\cdot$ lik-skema $^{3}$ :

$$
\begin{aligned}
& {\left[[\mathrm{a}]_{\mathrm{Ai}} \cdot l i k\right]_{\mathrm{Aj}} \leftrightarrow\left[\operatorname{soos} \mathrm{SEM}_{\mathrm{Ai}}\right]_{\mathrm{Aj}}} \\
& \text { jammer.lik; lief.lik; ryk.lik; siek·lik, }
\end{aligned}
$$

waar [a] = enige stam(allomorf); $\mathrm{A}=$ deelversamelingklas van adjektiewe en bywoorde of adverbia (kyk Figuur 1); $\mathbf{N}=$ naamwoord; $\mathrm{P}=$ frase; SEM = semantiek of betekenis van die betrokke stam; $i$ en $j$ = indekseringstekens; en die dubbelpyl op die ooreenkoms tussen die realiserings- en konseptualiseringspool dui (kyk Van Huyssteen 2017 vir 'n gedetailleerde uiteensetting van die noteringskonvensie).

Komplekse wat met die afleidingsmorfeem $\cdot i g$ gevorm word, word meestal as adjektiewe gebruik (byvoorbeeld bekk.ig, drift.ig en ernst.ig; Kempen 1969:506). Sulke adjektiewe kan ook meestal as bywoorde gebruik word: vergelyk 'n driftige ${ }_{\mathrm{ADI}}$ toespraak en driftig ${ }_{\mathrm{ADV}}$ beduie; 'n ernstige ${ }_{\mathrm{ADJ}}$ man en ernstig ${ }_{\mathrm{ADV}}$ praat met die kinders. Volgens Kempen (1969:507) funksioneer slegs een geval, te wete naarstig, uitsluitlik as bywoord. Soos reeds hier bo in die etimologiese analise aangetoon is, is dit duidelik dat huidig ook aan hierdie gevestigde woordvormingspatroon van Afrikaans voldoen, dan wel met die betekenis [MET DIE AARD VAN DIE HEDE].

Wanneer $\cdot$ ig-woorde as prenominale attributiewe adjektiewe gebruik word, word hulle konsekwent met behulp van die attributiewe $\cdot e$ verbuig en is dus nie vir verdere morfologiese prosesse beskikbaar nie. Dit is m.i. op grond van die hoë frekwensie en prominensie van huidig.e $e_{\mathrm{ADI}}$ (teenoor die lae frekwensie van huidig $_{A D}$ ) dat taalkenners tot nou toe die aanname gemaak het dat huidiglik nie 'n moontlike bousel is nie. Ons moet egter daarop let dat waar die attributiewe $e$ verdere morfologiese prosesse uitsluit, dit nie die $\cdot i g$-skema geld nie; vergelyk byvoorbeeld gevalle soos mens.waard.ig.heid, ge.mat.ig.d.e en breed.voer.ig.er. Die woord huidig ${ }_{\mathrm{A}}$ is dienooreenkomstig as basis vir die lik-skema in (5) beskikbaar.

Kempen (1969:535) wys daarop dat lik as toevoer werkwoorde, selfstandige naamwoorde en byvoeglike naamwoorde kan hê en dat die afvoer byvoeglike naamwoorde en bywoorde is 'waarvan (a) die meeste albei funksies kan hê en (b) enkeles net bwe. is, bv. beswaarlik, dadelik, deerlik, gewoonlikens'. Dit sou dus in beginsel moontlik wees dat huidiglik óf beide funksies kan hê, óf slegs as bywoord funksioneer. In Van Huyssteen (2018) word dié saak verder ondersoek, maar wat hier relevant is, is die feit

2. Slegs die tersaaklike aspekte van die $\cdot i g$-skema word hier weergegee en behandel Vir'n volledige oorsig, kyk Kempen (1969:506-510).

3. Slegs die tersaaklike aspekte van die $\cdot$ lik-skema word hier weergegee en behandel. Vir'n volledige oorsig, kyk Kempen (1969:534-539). 
dat lik sonder twyfel ook as adverbialiseerder in Afrikaans (soos ook · lijk in Nederlands - vgl. Booij 2018) optree. Gegewe dat daar ander bywoorde (en selfs prominente gevalle soos dadelik en moontlik) is wat op lik eindig, kan ons die konstruksionalisering (Hüning \& Booij 2014) van huidiglik motiveer aan die hand van analogisering as meganisme wat tot taalverandering lei (Traugott \& Trousdale 2013). Nóg faktore wat gebruik kan word om die konstruksionalisering van huidiglik te motiveer, word hier onder voorgehou.

Soos Combrink (1995a) merk Kempen op dat daar 'meesal ' $n$ mate van betekenisintensivering in woorde op -lik' is (1969:538). Hy gaan voort:

'Miskien verklaar dit waarom so dikwels, logies gesproke oorbodiglik, 'n -lik-vorm gebruik word wanneer die woordkorrelaat van die stam daarsonder feitlik dieselfde sou beteken, bv.

$\begin{array}{ll}\text { gans onmoontlik: } & \text { ganselik onmoontlik } \\ \text { 'n gek spulletjie: } & \text { 'n geklike spulletjie } \\ \text { 'n goddelose spul: } & \text { 'n goddelooslike spul } \\ \text { naarstig soek: } & \text { naarstiglik soek, ens. }\end{array}$

Die lys [van 153 woorde wat op -lik eindig] bevat 13 sulke gevalle, naamlik nog ryklik, sekerlik, sieklik, sotlik, stiptelik, vryelik, vuriglik, wonderbaarlik, wyslik. (Kempen 1969:538)

Hiervolgens sou 'n mens dit hipoteties kon stel dat die voorbeeldsin in (6), wat uit VivA-KPO onttrek is, met meer nadruk as (7) herskryf kan word. Of 'n skrywer of spreker dit so bedoel, en of 'n leser of hoorder dit so interpreteer, is stof vir verdere navorsing. Wat egter binne die konteks van hierdie artikel van belang is, is dat dit as nóg 'n motivering vir die konstruksionalisering van huidiglik dien. In navolging van Traugott en Trousdale (2013:27-29, 198-203) kan gesê word dat die aanvangskonteks 'n uitbreiding van die pragmatiek (te wete die intensie om te benadruk) behels en dat dit gevolglik tot die simbolisering daarvan (oftewel semantisering, d.i. die vorming van 'n vorm-betekenis-paar) lei deur van die adverbialiserende $\cdot l i k$ gebruik te maak. Hierdie suffiks dien egter nie net die doel om uitdrukking aan die nadruksbehoefte te gee nie, maar ook om potensiële woordsoortelike meerduidigheid eksplisiet op te klaar (kyk ook weer die opmerking oor seker vs. sekerlik hier bo):

6. Gevolglik is daar huidig geen wettige mark vir renosterprodukte nie.

7. Gevolglik is daar huidiglik geen wettige mark vir renosterprodukte nie.

Tot slot 'n waarneming oor die suffikskombinasie .ig.lik: Anders as by kombinasies soos $\cdot e n d /$ theid of $\cdot i g \cdot h e i d$, maak Kempen (1969) geen melding van die kombinasie $\cdot i g \cdot l i k$ nie. Dit laat 'n mens dus wonder of ig.lik wel 'n 'geldige' kombinasie van suffikse is. Twee argumente wat die geldigheid van $\cdot i g \cdot l i k$ ondersteun, kan aangevoer word:

- Woorde wat op ·ig.lik eindig, kom reeds voor in van die oudste tekste wat in formele Standaardafrikaans geskryf is. In die 1911-1920-gedeelte van die Historiese Korpus van Standaardafrikaans (HKSA) (Kirsten 2015) is daar byvoorbeeld drie gevalle, te wete goed-gunstiglik [sic], naarstiglik en gewilliglik. In al die periodes daarna tref ons ook $\cdot i g \cdot l i k$-woorde in die HKSA aan (met huidiglik wat sy opwagting vir die eerste keer in die 2001-2010-periode maak).

- Die ·ig.lik-kombinasie kom ook dikwels in hedendaagse geskrewe Afrikaans voor; vergelyk Van Huyssteen (2018).

\section{Argument: Die gebruik van die suffiks ·lik as adverbialiseerder is anglisisties}

Die doel van hierdie artikel is hoegenaamd nie om 'n bydrae tot die anglisismedebat ${ }^{4}$ te lewer nie, behalwe om dit te stel dat ons daarvan bewus moet wees dat daar in den brede twee benaderings tot die begrip 'anglisisme' is, te wete preskriptiewe beskouings (bv. Carstens 2018, wat anglisismes in die hoofstuk oor taalsuiwerheid bespreek) en deskriptiewe beskouings (bv. Donaldson 1991, wat anglisismes binne die konteks van taalkontak en -verandering hanteer). In eersgenoemde beskouings is daar gewoonlik 'n 'negative value judgement on the term' (Donaldson 1991:61, spesifiek ook gesê oor Combrink 1984 se hantering van die begrip); in laasgenoemde beskouings val die klem op 'any instance of an English lexical, structural, and phonological element in [ $a$ language] that can be formally related to English' (Onysko 2007:90). Enige vorm van Engelse beïnvloeding deur taalkontak word dusdanig sonder enige waardeoordeel as anglisisties gesien (Onysko 2007:91), insluitende leksikale ontlening, kodewisseling, semantiese verskuiwings, leenmorfologie, uitspraakverskynsels, of enige ander produktiewe gebruik van Engelsagtige konstruksies. In die res van hierdie artikel gebruik ek die term 'anglisisme' vir beskouings van die eerste soort, teenoor die term 'Engelsheid' vir enige konstruksie wat onder Engelse invloed in Afrikaans waargeneem kan word.

Volgens my interpretasie van die literatuur oor huidiglik, is alle standpunte oor die vermeende anglisistiese aard van die woord gesetel in twee verbandhoudende argumente. Die een argument lui dat huidiglik'n morfeem-vir-morfeem-vertaling van die Engelse presently (Combrink 1995c) is. Aangesien hierdie argument nêrens in die literatuur behoorlik beredeneer word nie, kan ons slegs aannames daaroor maak. Ek vermoed dat huidiglik volgens hierdie siening geglosseer sal word soos in (8):

8. huidig.lik

present.ADVZ

'presently'

Daar is m.i. ten minste drie probleme met hierdie analise en argumentasie:

- Dié analise veronderstel die bestaan van huidig, terwyl agiteerders téén huidiglik juis beweer dat huidig nie in Afrikaans voorkom nie - slegs huidige. Hierdie twee

4. Vergelyk Onysko (2007:5): 'The problem of what is an anglicism has stirred intense debates and still remains inconclusive and controversial today.' 
standpunte weerspreek en ondergrawe mekaar dus oor en weer.

- Die analise misken die feit dat huidiglik eintlik na regte (diachronies) geanaliseer moet word as huid.ig.lik, of te wel ([\{hede\} ig] lik). As 'n mens wil argumenteer dat huidiglik'n morfeem-vir-morfeem-vertaling van presently is, moet ' $n$ mens dus veronderstel dat presently ook uit drie morfeme bestaan. Om daarby uit te kom, moet present teruggevoer word na die Latynse præ. ('voor'), plus esse ('om te wees'), en dan moet præ. gelykgestel word aan hede (of sy historiese allomorf huid.). Dit is vanselfsprekend 'n verkeerde analise.

- As die argument gevolg word, word die feit dat presently se primêre betekenis in Engels 'binnekort' is en dat die sekondêre betekenis 'tans; nou' is (vergelyk o.a. die American Heritage Dictionary 2016), ook misken.

Die ander argument hou hiermee verband, maar fokus sterker daarop dat $\cdot$ lik as adverbialiseerder onder Engelse invloed staan. Reeds in 1967 merk Van der Merwe 'n toename in die gebruik van $\cdot l i k$ onder invloed van Engels op, maar volgens hom (Van der Merwe 1967:170) gaan dit oor die nadruksfunksie van lik (terwyl hy niks oor die adverbialiseringsfunksie sê nie). Dit is egter glad nie duidelik op grond waarvan hy sê dat die Engelse ·ly ook, soos in Afrikaans, 'n nadruksfunksie het nie.

Hiemstra (1980:72-73) blyk die eerste outeur te wees wat die opmars van lik as adverbialiseerder aan die invloed van Engels toeskryf. In sy argumentasie dek hy egter twee opponerende standpunte: Aan die een kant is lik as 'deftigheidsvorm' (volgens hom in 'ons ouer taal, veral Bybelse taal', met as voorbeelde naarstiglik en goedgunstiglik), of 'nadruksvorm' (waar hy wys op sekerlik vs. seker) aanvaarbaar, maar in die res van die gevalle nie, byvoorbeeld vrywilliglik, onwettiglik en bitterlik (Hiemstra 1980:73). Dit is spesifiek uit laasgenoemde voorbeeld wat die subjektiwiteit van die argument duidelik is: Waarom sou 'Sekerlik!' as antwoord nadruklik (en aanvaarbaar) wees, maar 'Dit is bitterlik koud' as stelling nie? Waarom sou goedgunstiglik as deftig (en aanvaarbaar) beskou kan word, maar vrywilliglik nie? Die rede waarom die laasgenoemde gevalle vermy moet word, is omdat dit volgens Hiemstra (1980) oortollig en onder Engelse invloed is. Hy bied helaas geen klarigheid oor waar die grense tussen die aanvaarbare en onaanvaarbare gevalle lê nie, en ek kan ook nie moontlike kriteria versin nie.

Myns insiens kan 'n mens met geen stelligheid sê dat ·lik 'n anglisisme in Afrikaans is nie. Nog Kempen (1969) (wat ·lik uitvoerig bespreek), nog Gous (1974) (wie se verhandeling spesifiek oor $\cdot$ lik handel) maak enige melding van Engelse invloed op · lik, terwyl Verhage (1965:310) eerder meen dat $\cdot l i k$ 'aan die verhewe Bybeltaal ontleen is'. Met betrekking tot Nederlands sê Booij (2018) dat · lijk die ‘Dutch adverbial suffix par excellence and thus ... on a par with English adverbialising $-\mathrm{ly}^{\prime}$ is. Met 'n blik nog verder terug in die tyd meen Philippa et al. (2003-2009) dat .lik < lijk 'al algemeen aanwezig in alle Oudgermaanse talen' was. Om dus slegs op die Engelse aard van lik in Afrikaans te fokus, ontken die groter Germaanse agtergrond en ontwikkelingspad van dié morfeem. Dit ontken ook die feit dat bywoorde verskillend in verskillende Germaanse tale ontwikkel (Diepeveen \& Van de Velde 2010).

Deur nie op die anglisistiese aard van .lik te fokus nie, maar dit eerder te beskou as 'n Engelsheid, bied aan ons die geleentheid om die taalkontaksituasie in Suid-Afrika as nóg 'n motivering vir die konstruksionalisering van huidiglik (en ander bywoorde met ·lik) te sien. Dié standpunt sluit aan by Donaldson (1991:209): '... English "-ly" may simply have acted as a contributing factor to the frequency with which adverbs in -lik are encountered in Afrikaans compared with standard Dutch'.

Tot slot: 'n Kerndeel van 'n anglisismeargument is gewoonlik dat die vermeende anglisisme 'iets inheems (dit wil sê 'n woord of uitdrukking wat reeds in Afrikaans is) bedreig of verdring' (Carstens 2018:352). Volgens dié argument verdring huidiglik vorme soos nou, tans, deesdae, teenswoordig (Carstens 2018:134), op hierdie oomblik, in hierdie tyd (-HAT $\left.{ }^{3}\right)$ of soos sake nou staan $\left(\mathrm{HAT}^{6}\right)$. Ook hier raak die taalpraktisyn en taalgebruiker in die war, want in teëspraak met bogenoemde bronne, meen Combrink en Spies (1994) ' $[d]$ it is uit deftigdoenery dat gewone woorde soos nou, vandag, deesdae en op die oomblik vervang word deur AHI-woorde soos tans, by hierdie geleentheid, in ons moderne tyd, huidiglik (Amptenaraans), heden en op hierdie oomblik in die tyd'. [outeur se eie nadruk]. Daar is dus onder preskriptiwiste ook nie altyd eenstemmigheid oor wat aanvaarbaar is, al dan nie.

Desalnietemin, vir die anglisismeargument om te bly staan, moet 'n mens dus kan aantoon dat huidiglik met 'n hoër frekwensie as, of met 'n toename ten koste van hierdie alternatiewe woorde of frases voorkom. In Van Huyssteen (2018) word hierdie twee aspekte ook verreken.

\section{Gevolgtrekking}

Die woord huidiglik en sy basis huidig is al vir byna vier dekades 'n doring in menige taalkundige, taalpraktisyn, leksikograaf en taalgebruiker se vlees. Dit is boonop moontlik dié Afrikaanstalige grammatika- en stylkwessie wat die meeste in die openbare domein bespreek is. Ten spyte van alle besware deur preskriptiwiste, is beide woorde goed gevestig in eietydse geskrewe Afrikaans, soos blyk uit die ondersoek van Van Huyssteen (2018) - wat saam met hierdie artikel gelees moet word.

Die belangrikste bevinding van hierdie artikel is dat daar geen taalkundige besware teen huidig(lik) ingebring kan word nie. Stilistiese besware is meestal 'n kwessie van smaak, soos ook blyk uit talle gevalle waar taalkundiges en -praktisyns mekaar teëspreek oor wat aanvaarbare alternatiewe vir huidig(lik) is, of dit modieus of juis verouderd is, ensovoorts.

In antwoord op die preskriptiwistiese sienings, is daar in hierdie artikel'n deskriptiwistiese benadering gevolg. Vanuit dié perspektief probeer 'n mens juis verstaan waarom 'n 
woord soos huidiglik ontstaan het en steeds bly voortbestaan, ten spyte van die besware van gesaghebbendes. Binne 'n konstruksionaliseringsraamwerk is drie motiverings vir die bestaan van huidiglik aangebied:

1. Die morfeem .lik is 'n bekende en produktiewe adjektiveerder en adverbialiseerder in Afrikaans (en ander Wes-Germaanse tale). Dit is daarom nie vreemd dat huidig ${ }_{\mathrm{A}}$ met ·lik gesuffigeer word nie, selfs al sou dit oorbodig wees. Die verskynsel van oorbodigheid (kyk onder andere Braunmüller 2015; Langacker 2013:187-189; Wit \& Gillette 1999), spesifiek ook morfologiese oorbodigheid, verdien verdere navorsing.

2. Dat lik 'n nadruksfunksie het, word deur talle taalkundiges bevestig. Gegewe die grammatiese homonimie van huidig $_{\mathrm{A}}$ (d.i., dat dit as adjektief én bywoord kan funksioneer), word lik ook gebruik om hierdie inherente meerduidigheid eksplisiet op te los.

3. Binne die taalkontaksituasie in Suid-Afrika kan die moontlike invloed van die Engelse $\cdot l y$ op die Afrikaanse . lik nie ontken word nie. Dit is egter om verskeie redes nie verrassend nie - en allermins verkeerd! - gegewe dat die wedersydse beïnvloeding tussen Afrikaans en Engels (beide Wes-Germaanse tale) al deeglik gedokumenteer is. Die invloed wat Engels op Afrikaanse taalverandering het, is so natuurlik soos die invloed van Engels op Nederlands en Duits, die invloed van Duits op Nederlands, Nederlands op Afrikaans, en so meer. Die adverbialiserende funksie van ·lik kan dus as 'n Engelsheid beskou word, maar nie as 'n anglisisme nie.

Hierdie drie faktore werk gesamentlik en ewewigtig om die konstruksionalisering van huidiglik te motiveer. Of preskriptiwistiese bronne binnekort hierdie realiteit sal reflekteer, sal net die tyd leer.

\section{Erkenning}

Met dank aan Tom McLachlan en Suléne Pilon vir kommentaar op 'n eerste konsepweergawe van die artikel.

\section{Mededingende belange}

Die outeur verklaar hiermee dat hy geen finansiële of persoonlike verbintenis het met enige party wat hom voordelig of nadelig kon beïnvloed het in die skryf van hierdie artikel nie.

\section{Literatuurverwysings}

AHD, 2016, American Heritage Dictionary of the English language, Houghton Mifflin Harcourt, Boston, MA.

ANNA, 2011, Pharos Groot Woordeboek Afrikaans en Nederlands, Pharos, Kaapstad. Basson, J., 2006, Politieke kaarte op die tafel, Politika, Kaapstad.

Booij, G., 2010, Construction morphology, Oxford University Press, Oxford.

Booij, G., 2018, -elijk, Taalportaal, besoek op 06 Mei 2018 by http://taalportaal.org/ taalportaal/topic/pid/topic-13998813292392024

Braunmüller, K., 2015, 'Competing tendencies in Germanic pronominal and deictic systems: The most general principle will prevail', in M. Hilpert, J.-O. Östman, C. Mertzlufft, M. Rießler \& J. Duke (eds.), New trends in Nordic and genera linguistics, pp. 11-27, De Gruyter, Berlin.

Carstens, W.A.M., 1989, Norme vir Afrikaans, 1e uitg., Van Schaik, Pretoria.
Carstens, W.A.M., 2003, Vermy dit! NWU Nuusbrief, Februarie, Noordwes-Universiteit, Potchefstroom.

Carstens, W.A.M., 2018, Norme vir Afrikaans, 6e uitg., Van Schaik, Pretoria.

Combrink, J.G.H., 1984, 'Wat is 'n anglisisme?', in T.J.R. Botha, J.G.H. Combrink \& F.F. Odendal (uitgs.), Inleiding tot die Afrikaanse taalkunde, bl. 83-106, Academica, Pretoria.

Combrink, J.G.H., 1993, 'Hoog praat is nie goed praat', Die Burger, 11 Januarie, bl. 7.

Combrink, J.G.H., 1995a, "Redes waarom "wettiglik," "naarstiglik" en "huidiglik" nié toutologieë is nie', Beeld, 23 Januarie, bl. 7.

Combrink, J.G.H., 1995b, 'Woordeboek nie altyd op datum', Die Burger, 26 Junie, bl. 11.

Combrink, J.G.H., 1995c, 'Geforseerde "huidiglik" kom uit Amptenaraans', Beeld, 6 Maart, bl. 7.

Combrink, J.G.H., 1996, “'Huidiglik” korrek as 51\% so sê', Beeld, 7 Oktober, bl. 7.

Combrink, J.G.H. \& Spies, J., 1994, Sakboek van regte Afrikaans, Tafelberg, Kaapstad.

De Villiers, M., 1959, Norme en afwykinge in die taal, Nasionale Pers, Kaapstad.

De Villiers, M., 1981, 'Modeverskynsels in die taal', Die Kerkbode 133(21), 4.

De Villiers, M., 1986, 'Los liewer “-lik" in Afrikaans', Rapport, 20 April, bl. 15.

De Vries, M. \& Te Winkel, L.A. (reds.), 1864-1997, Woordenboek der Nederlandsche taal [WNT], Martinus Nijhoff, 's-Gravenhage.

Diepeveen, J. \& Van de Velde, F., 2010, 'Adverbial morphology: How Dutch and German are moving away from English', Journal of Germanic Linguistics 22, 381-402. https://doi.org/10.1017/S1470542710000115

Donaldson, B.C., 1991, The influence of English on Afrikaans: A case study of linguistic change in a language contact situation, Academica, Pretoria.

Du Plessis, E.P., 1979, Die kennis gids tot moderne Afrikaans, Human \& Rousseau, Kaapstad.

Du Plessis, E.P., 1981, Die kennis gids tot moderne Afrikaans, Human \& Rousseau, Kaapstad.

Eksteen, L.C., 1985, Woord vir woord: Kort bydraes oor die woordeskat van Afrikaans, Macmillan, Johannesburg.

Gous, J.A., 1974, Die morfeem -lik in Afrikaans, Ongepubliseerde meestersverhandeling, Wits Universiteit, Johannesburg.

Hengeveld, K., 1992, Non-verbal predication: Theory, typology, diachrony, Mouton de Gruyter, Berlin.

Hengeveld, K., Rijkhoff, J.A.N. \& Siewierska, A., 2004, 'Parts-of-speech systems and word order', Journal of Linguistics 40, 527-570. https://doi.org/10.1017/S002222 6704002762

Hiemstra, L.W., 1980, Die juiste woord, Tafelberg, Kaapstad.

Hummel, M., 2014, 'The adjective-adverb interface in Romance and English', in P. Sleeman, F. van de Velde \& H. Perridon (eds.), Adjectives in Germanic and Romance, pp. 35-71, John Benjamins, Amsterdam.

Hüning, M. \& Booij, G., 2014, 'From compounding to derivation - The rise of derivational affixes through "constructionalization"', Folia Linguistica 48, 579-604. https://doi.org/10.1515/flin.2014.019

Kapp, S., 2014, 'Oor "huidiglik"', Facebook, besoek op 8 Desember 2017, by https:// www.facebook.com/Taalkommissie/posts/798646713525292

Kempen, W., 1969, Samestelling, afleiding en woordsoortelike meerfunksionaliteit in Afrikaans, Nasou, Kaapstad.

Kirsten, J., 2015, Historiese korpus van Standaardafrikaans 1.0. [HKSA], NoordwesUniversiteit, Vanderbijlpark.

Kirsten, J., 2016, Grammatikale verandering in Afrikaans van 1911-2010, Ongepubliseerde PhD-proefskrif, Noordwes-Universiteit, Vanderbijlpark.

La Grange, A.B., 1973, 'Tweejaarlikse wetenskaplike kongres en 68ste algemene jaarvergadering, Unisa, Pretoria, 15-19 Oktober 1973, Presidentsrede', Journal of the South African Veterinarian Association 45(1\&2), 15-20.

Langacker, R.W., 2013, Essentials of cognitive grammar, Oxford University Press, Oxford.

Luther, J. \& Pheiffer, F. (reds.), 2013, HAT taal- en feitegids [HAT language and fact guide], Pearson, Kaapstad.

Luther, J., Pheiffer, F. \& Gouws, R.H. (reds.), 2015, Handwoordeboek van die Afrikaanse taal, 6e uitg., Pearson, Kaapstad.

Müller, D. 2003. Skryf Afrikaans van A tot Z, Pharos, Kaapstad.

Müller, D. \& Pistor, S., 2011, Skryf Afrikaans van A tot Z, Pharos, Kaapstad.

Odendal, F.F. (red.), 1994, HAT: Verklarende handwoordeboek van die Afrikaanse taal, 3e uitg., Perskor, Midrand.

Onysko, A., 2007, Anglicisms in German: Borrowing, Lexical Productivity and Written Codeswitching, De Gruyter, Berlin.

Philippa, M., Debrabandere, F., Quak, A., Schoonheim, T. \& Van der Sijs, N., 20032009, Etymologisch Woordenboek van het Nederlands, Amsterdam University Press, Amsterdam.

Prinsloo, A.F., 2003, “'Huidiglik" - 'n sondebok (bet. 1)"', in W.F. Botha (red.), 'n Man wat beur, bl. 305-313, Buro van die WAT, Stellenbosch.

Prinsloo, A.F., 2013, 'Taalkruie: Huidiglik agterbaks', Volksblad, 29 Augustus, bl. 7.

Prinsloo, A.F. \& Odendal, F.F., 1995, Afrikaans op sy beste: Hulp met moderne taalkwessies, Van Schaik, Pretoria. 
Scholtz, J.J.J., 1990, 'Onbekend: Oor huidiglik', Die Burger, 23 Julie, bl. 11. Spies, J., 1990, 'Onbekend: Oor huidiglik', Die Burger, 07 Mei, bl. 9.

Taalkommissie van die SA Akademie vir Wetenskap en Kuns, 2017, Afrikaanse Woordelys en Spelreëls, 11e uitg., Pharos Woordeboeke, Kaapstad.

Theron, A.S., 1964, Aspekte van die bywoord in Afrikaans, Ongepubliseerde meestersverhandeling, Universiteit Stellenbosch, Stellenbosch.

Traugott, E.C. \& Trousdale, G., 2013, Constructionalization and constructional changes, Oxford University Press, Oxford.

Van der Merwe, H.J.J.M., 1956, Afrikaanse taalkwessies, Van Schaik, Pretoria.

Van der Merwe, H.J.J.M., 1967, Die korrekte woord: Afrikaanse taalkwessies, Van Schaik, Pretoria.

Van der Merwe, H.J.J.M. \& Ponelis, F.A., 1982, Die korrekte woord: Afrikaanse taalkwessies, Van Schaik, Pretoria.

Van der Merwe, H.J.J.M. \& Ponelis, F.A., 1991, Die korrekte woord: Afrikaanse taalkwessies, Van Schaik, Pretoria.
Van Huyssteen, G.B., 2017, 'Morfologie', in W.A.M. Carstens \& N. Bosman (reds.) Kontemporêre Afrikaanse taalkunde, 2e uitg., Van Schaik, Pretoria.

Van Huyssteen, G.B., 2018, "n Korpusondersoek na "huidiglik"', Literator (Ter perse).

Van Schoor, J.L., 1983, Die grammatika van standaard-Afrikaans, Lex Patria, Kaapstad.

Van Veen, P.A.F. \& Van der Sijs, N., 1997, Etymologisch woordenboek: De herkomst van onze woorden, Van Dale Lexicografie, Utrecht.

Van Wijk, N., 1936 [1912], Franck's Etymologisch woordenboek der Nederlandsche taal, M. Nijhoff, Den Haag.

Verhage, J.A., 1965, 'Deftige en gemeensame vorme in die sinsverband van ou Kaapse taal', Tydskrif vir Geesteswetenskappe 5, 307-323.

VivA-KPO: Virtuele Instituut vir Afrikaans, 2017, Korpusportaal: Omvattend, besoek op 30 April 2018, by http://viva-afrikaans.org.

Wiktionary, 2018, 'heutig', besoek op 30 April 2018, by https://en.wiktionary.org/ wiki/heutig

Wit, E.-J.C. \& Gillette, M., 1999, What is linguistic redundancy?, Technical report, University of Chicago, Chicago, IL. 